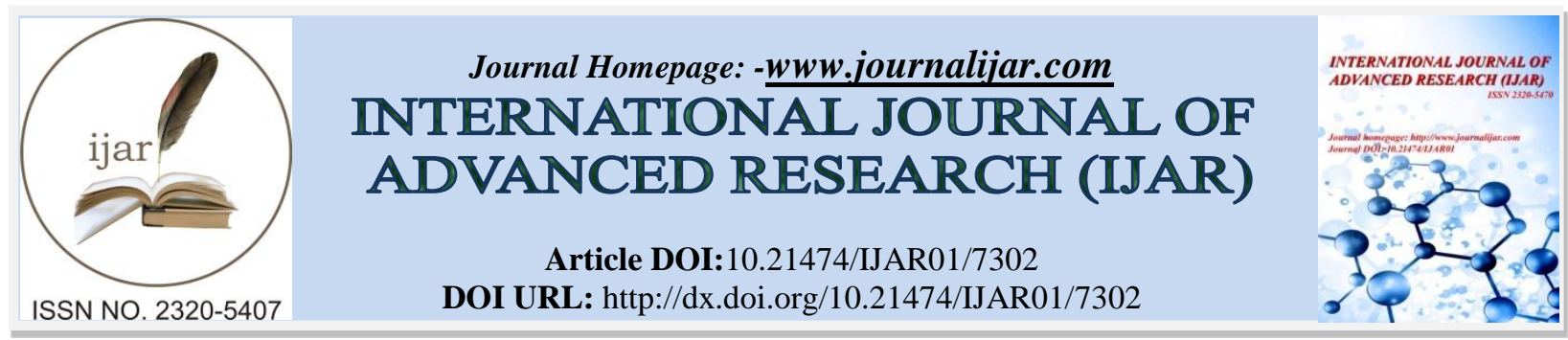

RESEARCH ARTICLE

\title{
A STUDY TO ASSESS THE EFFECTIVENESS OF INFORMATION EDUCATION AND COMMUNICATION (IEC) ON KNOWLEDGE AND PRACTICE OF NUTRITIONAL STATUS AMONG ADOLESCENT GIRLS IN SELECTED HIGH SCHOOLS OF KOLAR TALUK.
}

\author{
Mrs Mary Minarva Mrs Malathi K V and Bhanupriya R
}

\section{Manuscript Info}

Manuscript History

Received: 16 April 2018

Final Accepted: 18 May 2018

Published: June 2018

\begin{abstract}
Background: The growth and prosperity of a nation depend heavily on the nutritional status and development of adolescent girls as they not only constitute one tenth of population but also influence the growth of remaining population. Diets of Indian adolescent girls especially in rural areas are inadequate in terms of quality and quantity.

Material and Methods: for the present study true experimental design was adopted, by using simple random sampling technique, 60 (30 Control and 30 Experimental) adolescent girls were selected from selected High Schools of Kolar taluk. The data was collected by structured knowledge questionnaire and 24 hours recall.

The pretest was conducted on the 1st day for control and experimental group subjects. Information Education and Communication (IEC) was administered lasting for 45 minutes for Experimental group. Post-test was conducted 15 days after the intervention for both the groups.

Results: The findings of the study revealed that there was a statistically significant difference between posttest knowledge scores of control

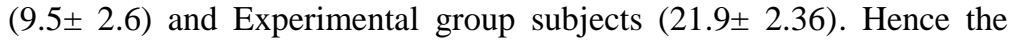
null hypothesis was rejected. It shows that Information Education and Communication (IEC) were effective to increase the knowledge and practice score among Adolescent girls nutritional status. It also shows that there was significant association of posttest knowledge scores with selected socio-demographic variables.

Conclusion: Health maintenance is the self- responsibility of each individual. The present study encourages the adolescent girls to impart health education using various methods to improve their nutritional status and to become healthy.
\end{abstract}

Copy Right, IJAR, 2018,. All rights reserved.

\section{Background:-}

Adolescence is the transitional period between childhood and adulthood. During this period individual move towards physical and psychological maturity, and economic independence and acquire their adult identity. During puberty that body composition and biologic changes emerge which affect gender specific nutrient needs. Nutrient needs parallel the rate of growth with the greatest nutrient demands occurring during the peak velocity of growth. At the peak of adolescent growth spurt the nutritional requirement may be twice as high as those of remaining period of adolescence. $^{(1)}$ 
Adolescent girls, constitute nearly one tenth of Indian population, form a crucial segment of the society. In general, adolescent girls are the worst sufferers with various forms of malnutrition because of their increased nutritional needs and low social power. ${ }^{(1)}$

\section{According to the 2014 census:-}

1. Globally anemia affects 1.62 billion people, which corresponds to $24.8 \%$ of the population.

2. 16 million adolescent comprise $22 \%$ of India's total population.

3. In rural Karnataka the prevalence rate is high $45.2 \%$ are suffering from anemia during the age group of $10-19$ yrs. ${ }^{(1)}$

4. National family health survey statistics reveal that every second Indian women is anemic. ${ }^{(2)}$

According to National Nutrition Monitoring bureau report, in Karnataka $10 \%$ adolescents are severely undernourished and $75 \%$ are moderately nourished $15 \%$ of adolescents are severely stunted and $60 \%$ are moderately stunted. ${ }^{(3)}$

According to (NFHS):-

More than half of women in India (55\%) have anemia, including $39 \%$ with mild, $15 \%$ with moderate and $2 \%$ with severe as adolescent anemia is the greatest nutrition problem. ${ }^{(4)}$

A community based cross sectional study was conducted on nutritional status of adolescent girls in Peerwadi village, Belgam district Karnataka. By using Systematic random sampling technique, 400 adolescent girls of (10-19yrs) were selected. Information is collected by interview and practice of $24 \mathrm{hrs}$ recall method and anthropometric data analysed by National centre for health statistics. The result shows that $10-14$ yrs girls were more stunted (63.82\%) as compared to 15 to $19 \mathrm{yrs}(40.84 \%)$ and the deficit intake of food is $40.99 \%$. as majority of girls were having dietary intake less than 50\%.Further, emphasized on improvement of nutritional status of adolescent girls through counseling and health education is needed. ${ }^{(5)}$

Health teaching is an integral part of nursing and it emphasizes a scientific attitude towards health which is very important for moderate healthy living. Community- level nutrition education should be designed to help families with limited resources to make food choices that will improve their diet and health. $\left({ }^{6)}\right.$ Hence the present study was undertaken with following objectives.

\section{Aims:-}

1. To assess the Knowledge and practice of nutritional status among adolescent girls in both Control and Experimental group by using structured knowledge questionnaire.

2. To determine the effectiveness of IEC packages by comparing pre and post test knowledge scores in both control and Experimental group

3. To determine the association between the knowledge and practice with selected demographic variables on nutritional status of adolescent girls.

\section{Settings and Design:-}

Kembodi Janaths High school high and devarayasamudra high school Kolar Taluk and the study design is true experimental experimental with pretest posttest control group design .

\section{Methods and Material:-}

A pretest posttest control group design was adopted for the study. The setting was two selected government high schools of Kolar taluk. simple random sampling technique was used to select 60 adolescent girls ( 30 in experimental 30 in control group). The data collection tool consisted of demographic profroma, and structured questionnaire on knowledge, regarding nutritional status and practice was assessed by collecting 24hours nutritional recall. Ethical clearance was obtained from institutional ethical committee. Formal written permission was obtained from head masters of Kembodi high school and Devarayasamudhra high school. Pre test was conducted to 60 adolescent girls (30 in experimental 30 in control group). One week of 24 hours recall was collected from adolescent girls and IEC programme was given to experimental group.post test was conducted for both the groups on the fifteenth day of IEC programme. Data was analysed using descriptive statistics mean, median and standard deviation inferential statistics such as t-test, chi- square tests. 


\section{Statistical analysis used:-}

1. Descriptive Statistics: 1.sociodemographic data was analysed by using frequency and percentage.

2. Knowledge was assessed by using mean and Standard deviation

3. Effectiveness of Information, education and communication(IEC) was analysed by t- test

4. Association of knowledge score with socio-demographic data was analysed by using chi square test.

\section{Results:-}

Socio demographic variables of adolescent girls:-

The study finding reveals that in terms of socio-demographic variables majority (46.6\%) of the Experimental group as well as in the control group $(60 \%)$ subjects were in the age group of 14 yrs. In terms of religion majority ( $90 \%$ \& $86.6 \%$ ) were Hindus in both the groups and With regard to Type of family majority $46.6 \%$ of the experimental group as well as in the most $50 \%$ of the control group 50\% samples belongs to the Nuclear family. In terms of type of food majority $(86.6 \% \& 76.6 \%)$ of samples were taking mixed diet. In terms of education of the mother, majority (33.4\%) of the subjects in study group are having primary education and in control group the majority are (36.6\%) are not educated. With regard to parents occupation majority of the subjects $(70 \%$ \& $76.6 \%)$ were agricultural workers in both study and control group and majority $(50 \% \& 46.6 \%)$ were having socio economic status Rs. $<5000 /$ month. With regard to Attainment of menarche (53.4\%) were under 13years in experimental group and $(53.4 \%)$ were under 14years in control group.

Table1:-Overall pre-test and post test distribution of Mean Knowledge scores of subjects N=60

\begin{tabular}{|c|c|c|c|c|c|c|c|c|c|c|c|}
\hline \multirow{2}{*}{$\begin{array}{c}\text { Sl. } \\
\text { No. }\end{array}$} & $\begin{array}{c}\text { knowledge } \\
\text { Variable }\end{array}$ & $\begin{array}{c}\text { No. } \\
\text { of } \\
\text { Item }\end{array}$ & $\begin{array}{c}\text { Max } \\
\text { score }\end{array}$ & \multicolumn{4}{|c|}{$\begin{array}{c}\text { Experimental group } \\
\left(\mathrm{n}_{1}=30\right)\end{array}$} & \multicolumn{3}{c|}{$\begin{array}{c}\text { Control group } \\
\left(\mathrm{n}_{2}=30\right)\end{array}$} \\
\cline { 5 - 12 } & & & Range & Mean & SD & $\begin{array}{c}\text { Mean } \\
\boldsymbol{\%}\end{array}$ & Range & Mean & SD & $\begin{array}{c}\text { Mean } \\
\text { \% }\end{array}$ \\
\hline 1 & Pre test & 30 & 30 & $16-02$ & 9.3 & 3.09 & $31 \%$ & $18-02$ & 8.4 & 2.1 & $28 \%$ \\
\hline 2 & Post test & 30 & 30 & $28-13$ & 21.9 & 2.36 & $73 \%$ & $18-04$ & 9.5 & 2.6 & $31.6 \%$ \\
\hline
\end{tabular}

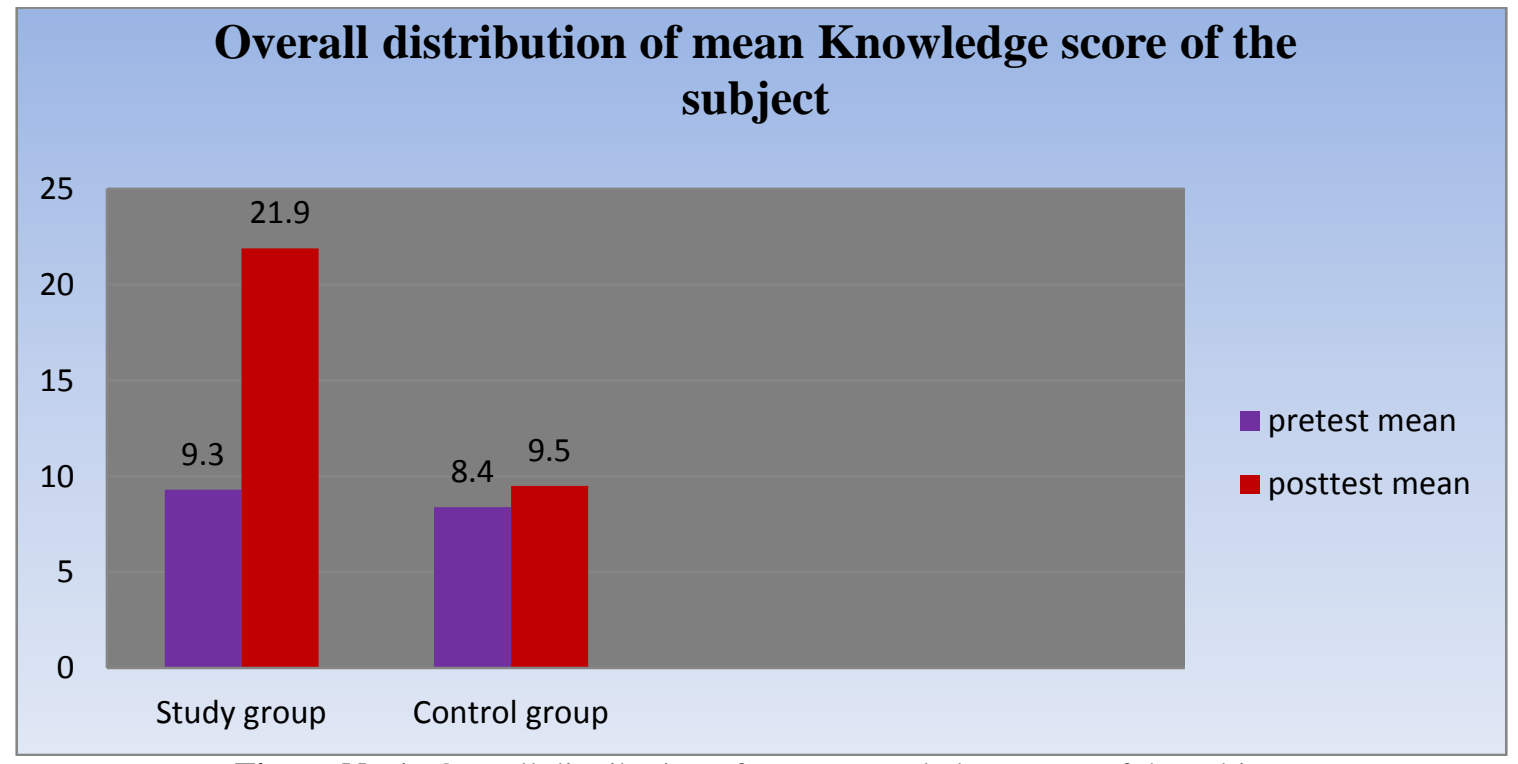

Figure No.1:-Overall distribution of mean Knowledge scores of the subject

Table -1 and Figure 1 represented by bar diagram shows that the overall mean knowledge score of subject regarding nutritional status in Control group is 8.4 in pretest and 9.5 in post test and in Experimental group is 9.3 in pretest and 21.9 in post test. Thus the study findings indicate that the pre-test knowledge of the subjects in Control group and Study group had inadequate knowledge. 
Table 2:-Overall distribution of Mean Practice scores of subjects $\mathbf{N}=\mathbf{6 0}$

\begin{tabular}{|c|c|c|c|c|c|c|}
\hline \multirow[t]{2}{*}{ SI.No } & \multirow[t]{2}{*}{ Practice tests } & \multirow[t]{2}{*}{ Nutrients } & \multicolumn{2}{|c|}{$\begin{array}{l}\text { Experimental group } \\
\qquad\left(\mathrm{n}_{1}=30\right)\end{array}$} & \multicolumn{2}{|c|}{$\begin{array}{l}\text { Control group } \\
\qquad\left(\mathrm{n}_{2}=30\right)\end{array}$} \\
\hline & & & Mean & $\mathrm{SD}$ & Mean & $\mathrm{SD}$ \\
\hline \multirow[t]{5}{*}{1} & \multirow[t]{5}{*}{ pretest } & Energy K.Cal & 1749.7 & 26545.9 & 1839.7 & 55236.4 \\
\hline & & Protein $(\mathrm{g})$ & 48.46 & 3033.6 & 40.64 & 1219.3 \\
\hline & & Fat $(\mathrm{g})$ & 14.6 & 440.4 & 14.59 & 437.8 \\
\hline & & Calcium (mg) & 117.46 & 3523.86 & 320.4 & 2537.43 \\
\hline & & Iron $(\mathrm{mg})$ & 17.87 & 534.4 & 18.43 & 552.9 \\
\hline \multirow[t]{5}{*}{2} & \multirow[t]{5}{*}{ posttest } & Energy K.Cal & 2276.467 & 26452.4 & 1736.73 & 4424.14 \\
\hline & & Protein $(\mathrm{g})$ & 49.53 & 4473.8 & 38.95 & 5270.96 \\
\hline & & Fat ( g) & 14.97 & 52.76 & 14.93 & 59.96 \\
\hline & & Calcium (mg) & 118.02 & 1277.5 & 207.7 & 9985.7 \\
\hline & & Iron (mg) & 18.38 & 30.65 & 18.01 & 32.56 \\
\hline
\end{tabular}

The over all mean Practice score in Control group is found to be in pretest are 1839.7 K.Cal , 40.64g of protein, $14.59 \mathrm{~g}$ of fat, $320.4 \mathrm{mg}$ of calcium and $552.9 \mathrm{mg}$ in Control group and in the post test after the intervention the Experimental group shows the mean of 2276.4K.cal, Protein 49.53g, fat $14.97 \mathrm{mg}$, calcium $118.02 \mathrm{mg}$ and Iron $18.38 \mathrm{mg}$. Thus the study findings indicate that the subjects in Experimental group improved the intake levels of Energy 526.76 K.cal, Protein $1.07 \mathrm{~g}$, Fat $0.73 \mathrm{~g}$, Calcium $0.02 \mathrm{mg}$ and Iron $0.5 \mathrm{mg}$ showing the effectiveness of IEC.

Table 3:-Comparison of post test mean scores between control and experimental group regarding Knowledge and Practice $\mathbf{N}=\mathbf{6 0}$

\begin{tabular}{|c|c|c|c|c|c|c|c|c|}
\hline SI.No & Groups & Tests & mean & SD & $\begin{array}{l}\text { Unpaired } \\
\mathrm{t}_{\text {cal }} \text { value }\end{array}$ & df & $\mathrm{P}$ value & Inference \\
\hline \multirow[t]{2}{*}{1} & $\begin{array}{c}\text { Experimental } \\
\text { Group }\end{array}$ & posttest & 21.9 & 2.36 & \multirow[t]{2}{*}{18.68} & \multirow[t]{2}{*}{29} & \multirow[t]{2}{*}{$P<0.05$} & \multirow[t]{2}{*}{ SS } \\
\hline & Control group & posttest & 9.5 & 2.6 & & & & \\
\hline
\end{tabular}

Table 3 reveals that the comparison between posttest mean scores of unpaired t-test shows that there is a significant increase in Experimental group mean 21.9 than to control group 9.5 with the $t$ value of 18.68 which shows statistically significant changes.

$\mathbf{H}_{\mathbf{0 1}}$ :-Adolescent girls who receive IEC packages on nutrition status will not show a significant increase in level of knowledge and practice in post test. Hence $\mathrm{H}_{01}$ is accepted for the Practice. Hence $\mathrm{H}_{01}$ is rejected for the Knowledge aspect.

Table 4:-Comparison of post test mean scores between control and experimental group regarding Knowledge and Practice $\mathbf{N}=\mathbf{6 0}$

\begin{tabular}{|c|c|c|c|c|c|c|c|c|c|}
\hline \multirow[t]{2}{*}{ SI.No } & \multirow[t]{2}{*}{$\begin{array}{l}\text { Practice } \\
\text { tests }\end{array}$} & \multirow[t]{2}{*}{ Nutrients } & \multicolumn{2}{|c|}{$\begin{array}{c}\text { Study group } \\
\left(\mathrm{n}_{1}=30\right)\end{array}$} & \multicolumn{2}{|c|}{$\begin{array}{c}\text { Control group } \\
\left(\mathrm{n}_{2}=30\right)\end{array}$} & \multirow[t]{2}{*}{$\begin{array}{l}\mathrm{T} \text { cal } \\
\text { value }\end{array}$} & \multirow[t]{2}{*}{$\begin{array}{l}\mathrm{P} \\
\text { value }\end{array}$} & \multirow[t]{2}{*}{ Inference } \\
\hline & & & Mean & SD & Mean & SD & & & \\
\hline \multirow[t]{5}{*}{1} & \multirow[t]{5}{*}{ Posttest } & $\begin{array}{l}\text { Energy } \\
\text { K.Cal }\end{array}$ & 2276.467 & 26452.4 & 1736.73 & 4424.14 & 1.597 & $\mathrm{p}>0.05$ & NS \\
\hline & & Protein $(\mathrm{g})$ & 49.53 & 4473.8 & 38.95 & 5270.96 & 1.275 & $p>0.05$ & NS \\
\hline & & Fat ( g) & 14.97 & 52.76 & 14.93 & 59.96 & 0.996 & $p>0.05$ & NS \\
\hline & & $\begin{array}{l}\text { Calcium } \\
(\mathrm{mg})\end{array}$ & 118.02 & 1277.5 & 207.7 & 9985.7 & 1.155 & $\mathrm{p}>0.05$ & NS \\
\hline & & Iron (mg) & 18.38 & 30.65 & 18.01 & 32.56 & 0.658 & $\mathrm{p}>0.05$ & NS \\
\hline
\end{tabular}


Table 4 , showing that both the groups are different in their mean knowledge scores at pre-test level and the knowledge scores are increased after IEC to the Study group after the intervention. In the study group Energy, fat and Iron shows statistically significant level with the value of $p>0.05$. The mean scores of all the components of nutrient shows improved intake compared to the control group.

$\mathbf{H}_{\mathbf{0 1}}$ :-Adolescent girls who receive IEC packages on nutrition status will not show a significant increase in level of knowledge and practice in post test. Hence $\mathrm{H}_{01}$ is accepted for the Practice.

Association of Post-test knowledge of the subjects with socio demographic variables:-

The association between the knowledge scores with selected socio demographic variables such as Age , religion, type of family, type of food, education of the mother, parents occupation, family socio economic status and attainment of menarche. In order to find the association between post-test level knowledge the following null hypothesis was stated to test the level of significance at 0.05 levels.

$\mathbf{H}_{\mathbf{0 2}}$ :-There will not be statistically significant association between level of knowledge and practice regarding nutritional status among adolescent girls.

The chi square values of socio demographic variables such as age with $\chi^{2}$ value of 20.2 at df 2 , religion with $\chi^{2}$ value of 17.00 at df 1 , type of family with $\chi^{2}$ value of 4.12 at $\mathrm{df} 1$, type of food with $\chi^{2}$ value of 5.45 at $\mathrm{df} 1$,parents occupation with $\chi^{2}$ value of 12.57 at df 3 in experimental group and in control group religion with $\chi^{2}$ value of 4.29 at df 1 ,type of family with $\chi^{2}$ value of 7.50 at df 1 are significant at 0.05 level.

\section{Testing of the hypothesis:-}

$\mathbf{H}_{\mathbf{0 1}}$ :-Adolescent girls who receive IEC packages on nutrition status will not show a significant increase in level of knowledge and practice in post test.

Adolescent girls who received IEC packages on nutritional status have shown significant increase in level of Knowledge and on the nutritional status have shown an increase in their mean nutrient intake and there is no statistically significant level of Practice in terms of mean scores. Hence null hypothesis is accepted.

$\mathbf{H}_{\mathbf{0 2}}$ :-There will not be statistically significant association between level of knowledge and practice regarding nutritional status among adolescent girls.

The association of sociodemographic variables such as age, religion, type of family, type of food, parent's occupation in experimental group and in control group religion, type of family is significant at 0.05 levels.

The association of sociodemographic variables such as education of the mother, family socio economic status ,attainment of menarche were not having significant association in Experimental group .age in years, type of food, education of the mother, parents occupation ,family socio economic status and attainment of menarche were not having significant association in control group at 0.05 level. Hence $\mathrm{H}_{02}$ is accepted.

\section{References:-}

1. NFHS-3.Nutritional status of adults retrieved. Himalaya publishing house, 2011;(3):11-26.

2. Malnutrition statistics available from: 2014. By global hunger index. http://www.worldmalnutritionstatistics.com.

3. WHO global database on anaemia.2014 http://www.qlibdoc. Who.int/publications.

4. Adolescent health National mission.2014. http:www.nrhm.gov.in/nrhm...a/adolescent.../background.html.

5. Binay Singh.Malnutrition is Indias Silent emergency report.The Times of India.2013.

6. Sulakshana.S.Baliga, vijaya A.Naik.Nutritional status of adolescent girls residing in rural area.Journal of scientific society, 2014; Vol 411. (1)16.

7. Naipunya.Nutrition education for adolescent girls in slums.Hyderabad.Indian Institute of health and family welfare, 2009; vol.27. (4):151. 